\section{Seizing history: development and non-climate change in Small Island Developing States}

\author{
Godfrey Baldacchino \\ University of Malta, Msida, Malta and University of Prince Edward Island, \\ Charlottetown, Canada
}

\section{Development and non- climate change}

Received 14 February 2017 Revised 20 May 2017 Accepted 2 August 2017

\begin{abstract}
Purpose - This paper offers a critical review of climate change related initiatives in small island states, including Small Island Developing States (SIDS), which can end up as ontological traps: fuelled and supported by external donor agencies, thwarting out-migration and shifting scarce and finite resources away from other, shorter-term and locally spawned development trajectories and objectives.
\end{abstract}

Design/methodology/approach - This paper is based on a selective literature review. It clusters important themes found in published research and policy documents.

Findings - The results identify a burgeoning critical voice in regards to resilience and its legitimation of climate change driven projects in SIDS. This paper recommends a more nuanced approach which also privileges migration.

Originality/value - This paper provided a critical overview and synthesis of the immobility implicit in much climate change related work, through the critical lens of island studies and post-colonial studies.

Keywords Vulnerability, Climate change, Resilience, Development, Small island states, St Lucia

Paper type Research paper

\section{Introduction}

It was just another day at the office. Pugh (2016b) explores how affective attachments to ideals of post-colonial sovereign independence played out during a single day in April 2014 that he spent with town planners - two that he interviewed and others that eventually joined them - in their offices in Castries, the capital of St Lucia (an Eastern Caribbean small island state which gained independence from the UK in 1979). His analysis is closely aligned with the affect theory of Stewart (2011) and Berlant (2011); specifically, their concern for how people inhabit, dwell in and find their way through the more enigmatic and emotionally charged atmospheres of everyday life that cannot always be neatly captured by, or reduced to, coherent and rational conceptualisations of sovereign agency and disciplinary power at work.

As the conversation unfolds, these two planners repeatedly refer to current Western paradigms of resilience which, for them, reductively type Small Island Developing States

(C) Godfrey Baldacchino. Published by Emerald Publishing Limited. This article is published under the Creative Commons Attribution (CC BY 4.0) licence. Anyone may reproduce, distribute, translate and create derivative works of this article (for both commercial \& non-commercial purposes), subject to full attribution to the original publication and authors. The full terms of this licence may be seen at http://creativecommons.org/licences/by/4.0/legalcode

The author is grateful to Adam Grydehøj, Stefano Moncada and Jonathan Pugh for comments on an earlier draft. The usual disclaimers apply.

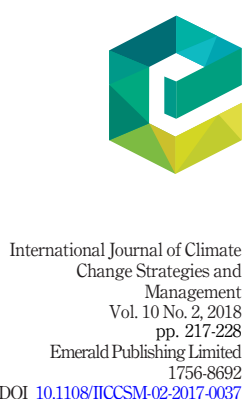

DOI 10.1108/JJCCSM-02-2017-0037 
IJCCSM 10,2

(SIDS) like St Lucia in terms of their vulnerabilities to disasters, catastrophes and emergencies.

This particular country has had its own fair share of economic yo-yoing: St Lucia was set up as a sugarcane plantation economy following European discovery. This was eclipsed by serving as a coal refuelling stop for ocean going vessels (1990-1930), an activity which was in turn overtaken by revenue from the sale of bananas during the 1960s, and then tourism surpassed the banana "green gold" in revenue in 1993 (Ellis, 2005). With each, often dramatic, ebb of a specific leading sector and the emergence of another, the socio-economy suffered painful dislocation: unemployment and relative poverty set in amongst the losers who sought to fight back against the change of fortune and who eventually adapted to or negotiated an honourable exit strategy: drawing on social or state welfare supports; switching to what is perceived as the next winning horse; and, as is also typical amongst small islanders, opting for permanent exi(s)le (Bongie, 1998) or a stint overseas. Climate change does not feature in these local strategies or considerations (Baldacchino and Bertram, 2009).

The planners in Castries are aware of this history: they contrast such discourses of cycles of vulnerability with more endogenous ideals of sovereign independence and post-colonial development. These planners complain that, while the resilient islander/subject "merely rides the waves of catastrophe and change", the subject of post-colonial independence "sought to seize history, and transform it". These islanders and public servants were particularly interested in positioning themselves against what is construed as the latest incarnation of a hegemonic and externally imposed, international development agenda. For all its positive spin by the international community, resilience discourse is constructed herein as one of the contemporary expansive "cultures of safety" and as such a regressive "step back" against the more progressive, but older, ideals of island national independence (Pugh, 2016b).

Resilience is largely about the capacity to "bounce back" from a violent, exogenous shock (Pelling and Uitto, 2001). It is, in itself, a welcome antidote to the depressing literature about chronic vulnerability that has gripped SIDS for over three decades, a narrative of "doom and gloom scenarios" (De Souza et al., 2015), that risks becoming so successful - especially in the context of sea level rise, sinking and disappearance - that at least one SIDS badly impacted by climate change has had to issue cautionary notes to inform potential donors that it was still open for business and welcomed foreign investment, in spite of a gloomy prognosis (Embassy of the Maldives in London, 2014). Yet, there is no resilience without underlying vulnerability; the former exists because of and feeds off the latter. Adaptation and mitigation measures to boost resilience merely affirm, lock in and naturalise a condition of insecurity and threat; they do not interrupt or transcend the perennial state of emergency which prevents even the idea of a different, more emancipatory kind of collective agency (Henderson and Denny, 2015, p. 365). Resilience numbs the consciousness of policymakers and publics in SIDS into a bio-politics whose object is "excess adaptive capacity": no more, no less (Grove, 2014, p. 240). Moreover, when small jurisdictions flex their resilience and their "creative agency" (Cooper and Shaw, 2009, p. 2), thus seeking to exploit their competitive advantage, they can still run into serious problems and traps laid slyly in their path by larger, developed countries who may see their economic hegemony at risk: Antigua and Barbuda's tortuous case against the USA at the WTO with respect to the cross-border supply of gambling and betting services is one example (Cooper, 2011) and the shaming and blacklisting of those small island states and territories which offer banking services demonised as immoral and parasitic "tax havens" is another (Vlcek, 2008; Rabidas, 2016). 


\section{Context}

Since the early 1990s, SIDS have lost their ability to bargain for aid and foreign investment by exploiting the opportunities presented by the US-USSR, post-Second World War rivalry. The demise of the Cold War threatened to consign SIDS to an invisibility and insignificance which would easily have spelt a reduction in international attention and aid flows, possibly threatening their survival and ushering in an irreversible outmigration of their brightest and ablest citizens (Neumann and Gstöhl, 2004). This scenario has, however, not materialised: SIDS have since found themselves back under the spotlight by virtue of being at the brunt of and nonclimate change another tense confrontation: this time, one with nature itself. The setting up of the Intergovernmental Panel on Climate Change coincided fortuitously with the collapse of the Berlin Wall and eventually of the USSR. Ever since the establishment of the vocal Alliance of Small Island States (AOSIS) in 1991 (currently with 39 full members, plus observers), SIDS have successfully positioned themselves as "hot spots" for climate change action for two inter-related reasons. First, as the dramatic milieux and witnesses of the all too tragic effects of climate change (and especially the consequences of sea level rise on low-lying atoll nations) and, second, by presenting themselves as the poster children of adaptation and mitigation measures to effectively address the same (Kelman, 2016). The underwater cabinet meeting by the Government of the Maldives in October 2009 was emblematic: a powerful media stunt, a "theatre in eco-cruelty", that spoke to, and itself galvanised further, this newfound interest in small island states (Chaudhuri and Enelow, 2014, p. 22). For these microstates, climate change may have become just as profitable a business opportunity as other unlikely "developmental strategies": money laundering, selling passports and citizenship, offering "flags of convenience" (Gay, 2014, p. 80). And while the scientific evidence on the impact of sea level rise on small island states remains mixed, a selective reportage highlights only the loss of land, disregarding stability or increases in land (Webb and Kench, 2010).

But this kind of attention has its costs. A dark and voyeuristic streak of tourism has emerged, with even more visitors interested in visiting "paradise" now, before these topos risk definitive sinking and wholesale disappearance (Barnett and Campbell, 2010; Farbotko, 2010a). Islanders thus become heroes and victims, subjects and objects of a morbid tourism niche industry that thrives on their unfortunate "sinking" predicament, a tragic situation, by the way, for which they certainly cannot be held responsible (Farbotko, 2010b).

Moreover, the channelling of international interest in measures intended towards adaptation or mitigation of climate change impacts has also tended to "crowd out" awareness of and concerns and funding for other, more mundane and immediate, policy priorities on SIDS: poverty reduction, health promotion, infrastructure provision, human resources and skills development and avenues for international mobility. Not wishing to miss out on the available (and always limited) largesse, various SIDS policymakers have been claiming "additionality", arguing for the tweaking of climate change funding policy such that it would supplement, rather than replace, existing funds and project priorities. Mainstream talk of "adaptation" within climate change science has typically been limited to and focused on adequate responses to the impacts of climate change rather than a broader definition, one that appropriately addresses the underlying factors that cause vulnerability in the first place and of which poverty is a critical component (Ayers and Huq, 2009; Burton et al., 2002). A necessarily selective focus on some coastal locations (and not others) for climate change-related projects has also tended to privilege the rich and politically powerful domestic elites, on SIDS as much as elsewhere (Urbina, 2016).

The current fixation on the impacts of climate change on SIDS is based on what is implicitly a western epistemological understanding of "the future" that may not necessarily 
IJCCSM 10,2 go down as well, or similarly, in other contexts and cultures and especially SIDS. In a sense, the future has arrived with a very solid knock on the door of the present, thanks to climate change action: no other current and well-funded projects, programmes and pursuits seek to impact on development agendas with a view to future (rather than present) scenarios as much as climate change (Urry, 2016). It is indeed ironic that while we are officially living in the age of the Anthropocene (Brondizio and Syvitski, 2016), we remain unable to know, let alone predict, the future, including a future that is admittedly also much our own making (Adam and Groves, 2007).

Moreover, planning for a tomorrow that does not (yet) exist is also, again implicitly, a middle-class concern because the poor are more fully engaged with surviving the present. Meanwhile, and never to shirk away from making hay while the sun shines, SIDS governments and NGOs may struggle to creatively exploit exogenous climate changedriven projects to service current and endogenous concerns: actual and planned climate change-related projects that have been planned and implemented in the various SIDS with a view to both satisfy international donors and speak to local needs as locally defined.

\section{Lingering post-colonialism}

The nature of relations between small island states and the international community smacks of a lingering post-colonialism. In spite of notions of autonomy and self-determination enshrined in the principles of sovereignty, independent states may find themselves following development trajectories that have been modelled and designed by others. Small island states, perhaps above all other jurisdictions, are ontological hostages of a development paradigm which they cannot fulfil: they lack a large population; they lack an industrialised and openly competitive economy; they even lack the essentials for sustainability and its mantra of self-reliance. And the growing popularity of "slow food" in the West - often in the name of food security and green and climate-friendly initiatives threatens to destroy SIDS' limited export possibilities. The residents of SIDS become the unwitting captives of a "deficit discourse" (Philpot et al., 2015) from which there is no escape, materially or cognitively.

There are islands of hope out there, which could lead by example: but the designation and persistence of appellations also codified within the United Nations and its agencies, means that some jurisdictions - such as Cape Verde, Maldives and Samoa - have been loath to miss out on various sources of funding as they "graduate" beyond the least-developed country category and continue to flaunt their chronic vulnerability (Santos-Paulino et al., 2010). Other successful small island states are by definition excluded from the SIDS category: the four European small states of Cyprus, Iceland, Ireland and Malta have all progressed away from being net recipients of UN or other multi-lateral largesse; yet, their impressive economic successes in recent years, hiccups notwithstanding, rarely feature in small state analysis as potential exemplars of "good practice". Meanwhile, Singapore (which is a member of the SIDS category, though not a recipient of funds, and neither a small nor a developing state) is often seen as the lonely exception or "paradox" to the otherwise debilitating predicament of the SIDS cluster, whose members are alleged to suffer from permanent structural handicaps (Briguglio, 1995; Briguglio et al., 2009).

The strictures of development have now been extended from the present and into the future by the new-found obligation to address the challenges of climate change, real or imaginary. The optics of undertaking such measures on a small island state add to the fascination of securing quick and visible results. The beguiling concept of "conspicuous sustainability" warns us about how the iconic and neatly geographically circumscribed status of a small island state engenders pursuits that may be notionally supportive of green 
practices but which may be simply illusory and cost ineffective (Grydehøj and Kelman, 2016). Indeed, when small island states complain that they suffer from a lack of economies of scale - a condition that has been empirically tested and proven, at least in relation to manufacturing (Briguglio, 1998) - there is no reason to believe that climate change efforts are not impacted by similar inefficiencies. What this means is that the optics trump the efficiencies: spending a dollar of international aid in a small island state may be more visible but ultimately produces a poorer return on investment than if the same dollar were invested in a larger state.

\section{Development and non- climate change}

Nationalism, version 2.0

The colonial experience, past and present, of many island jurisdictions has trapped these in a Western and metropolitan-oriented and determined conceptualisation of small island state identity; this prevents the pursuit of potential political and economic futures (Grydehøj, 2016). If, then, such colonial era mental boundaries stubbornly persist, what could conceivable take their place? The question is moot, especially when so many small island states and their societies - particularly in the Caribbean Sea and Indian Ocean - were themselves created by the colonial project (Baldacchino and Royle, 2010).

Sovereignty does offer an obvious possibility. The idealised nation state can provide a rubric for an alternative development path. "Nation building" efforts have been instigated by politico-economic elites in many small island states, in spite of the funding opportunities directed at other, less grandiose, climate-related ventures. Say, resources towards a quality early childhood education programme may be required, but the funding that is available is diverted, targeted instead to restore a mangrove forest or reseed a coral reef. Sadly, in many cases, these initiatives have exacerbated or succumbed to the limitations of scale. Expensive capital projects - power stations, centres of higher education, research and development facilities, waste management and recycling plants - have mushroomed, often concurrently, in neighbouring small island states, when the obvious economic solution is a confederal, supra-state partnership and cooperation and possibly with multiple but complementary investments. After all, the nation state (as much as its two constituent components) is itself a Western invention and concoction, and the borders imposed by contemporary political geography - the very same borders that delineate a state and its territory - project seas as obstacles and create an artificial barrier between cultures and people that may have mingled and traded openly for centuries, reminding us that islands do not have to be insular (Gosden and Pavlides, 1994). Hau'ofa (1994) still offers the most passionate critique of how islanders - in his case, in the Pacific - have traditionally navigated across huge swathes of ocean, using islands as hubs of a massive expanse of water they would call home; they should not allow themselves to be belittled by notions that they are the insignificant citizens of "small and developing island states" in an otherwise "empty" ocean (Ward, 1989).

Nationalism has been a powerfully shaping force throughout the twentieth century (Guibernau, 2013), and - with the Brexit vote in the UK and the election of Donald Trump to the Presidency of the USA in 2016 - indications are that it will remain as significant a force in the twenty-first century. The failure of federalist projects in the wake of decolonisation may be explained by their disregard for the allure and power of sovereign status. Once achieved, sovereignty can however be pooled from a position of relatively lower risk and greater security. After all, extantism is a powerful force: barring very few exceptions - the German Democratic Republic, Somaliland, South Yemen, Zanzibar - once a state, always a state (Schaffer, 1975, p. 25). I will not cite the European Union as a successful example of an inter-state federalist experiment: for all its palpable achievements in securing peace and prosperity in Europe over seven decades, it may be facing some serious existential 
IJCCSM

10,2

challenges of its own over the next few years (Sabel and Zeitlin, 2010; Fichera and Hänninen, 2016). However, the Organisation of Eastern Caribbean States (OECS) provides one promising model of how small island states sharing a regional geography can - while competing in other fields, such as promoting tourism and luring foreign direct investment combine resources and usurp the limitations of scale by crafting confederal institutions of shared governance (Roberts, Telesford and Barrow, 2015). The OECS slate of institutions includes a common currency, a common central bank, a common regional air space policy, a regional pharmaceutical procurement service, a court of highest appeal, as well as a Climate Change and Disaster Risk Management Unit which has a largely coordinating role (Turner, 2015; Huff-Rousselle and Burnett, 1996; CCU, 2016). This is surely impressive for a clutch of nine small and vulnerable states and territories whose largest member (St Lucia) has a resident population of 150,000 . Such inter-territorial and confederal approaches to governance and policy - rather than federal, as in the case of the doomed West Indies Federation (Mawby, 2012) - and including climate change-related initiatives, may be critical for long-term survival because the ultimate solution to the problem of sea level rise for people on low-lying island states may be wholesale emigration and depopulation which, by definition, can only be managed via international agreement. Kiribati is the pioneer here, training its youth in skills that are required abroad (Wyett, 2014), while buying land in Fiji in anticipation of a worst-case climatic scenario (Caramel, 2014); whereas the Maldives has both built an artificial island and is considering purchasing land in Australia (Collado, 2016).

\section{Change beyond climate change}

Indeed, the key policy stance that may prove to be the best response to climate change is the one that has been au courant throughout much of human history (and prehistory): migration. Nomadism, in its permanent guise during the age of hunter-gatherer societies, and its more sporadic variant following the agricultural revolution have been the signature response to environmental mishaps. It is only the current historical epoch that has engendered the mainstreaming of mitigation and adaptation: with its array of states jealous of their territorial reach and border control (Agnew, 1994) and a culture of "technological solutionism" bred from the advances of science and engineering and their resulting hubris (Morozov, 2014). The argument goes that nature is a force to be controlled and tamed, all the more so because the knowledge and funding to do so is finally possible and encouraged by SIDS elites whose beachfront properties may be amongst the most threatened by climate change impacts (Baldacchino and Kelman, 2014; Launder and Thompson, 2009).

Moreover, welcoming immigrants is not a naturally palatable human response for twenty-first century governments: it appears that Canada is the only member of the OECD "rich country club" whose government and general public are still openly pro-migration (The Economist, 2016). And thus, the discourse of resilience can easily become the nudge that (dangerously) obliges islanders to stay put and choose to fight, not resort to flight. No longer are island citizens meant to plan in terms of avoiding the possibility of traumatic experiences as are bound to result from catastrophic climatic events. Hurricanes, droughts, earthquakes along with sea level rise may very well be inevitable, but they now strongly invite resilience: they are powerful learning experiences from which individuals have to grow and prosper, collectively and individually. Vulnerability to threat, injury and loss is not simply to be condoned as a human condition but is the spur for proving one's inner strength and resourcefulness (Evans and Reid, 2014). Nomadism, in turn, is a circumstance condoned for and proscribed to the world's "high net worth individuals" (Palan, 2006; Vlcek, 2016). 
The option of migration is a condition that need not be reminded to the citizens of SIDS whose whole history has been a continuous and manifest engagement with their geography. For most SIDS today, a significant component of their economic success lies not in their endogenous capacity for value added - as may have been secured by their larger, continental neighbours - but in their ability to tap into and attract exogenous revenue: tourism, remittances, foreign bilateral and multilateral aid and other forms of rentier income (Baldacchino, 2006a; Connell, 2013; Prasad, 2004). The size and affluence of SIDS diasporas and their members - fully fledged "transnational corporations of kin" (Munro, 1990) - tend to be larger than those of local citizens (King and Connell, 1999; King, 2009), and it is migration, now increasingly circular, that fuels and nourishes these very welcome sources of extra-territorial revenue (Baldacchino, 2006b; Constant et al., 2013).

A large supporting cast of researchers, consultants, journalists, activists and celebrities are at hand to consolidate the plight of SIDS people as climate change victims, but not as environmental refugees, lest this nomenclature implicate other countries with responsibilities (Kelman, 2010). State sovereignty, expressed in terms of securitisation discourse, renders migration - as the natural response to environmental disaster - an increasingly difficult option to the residents and citizens of SIDS. The climate change script implicitly obliges SIDS citizens to hold fast and dig in, shore up defences and hope for the best. Resilience, as the flip side to vulnerability, is a welcome and optimistic take on SIDS and their ability to exploit opportunities; however, shorn of its upbeat rhetoric, the dice of resilience remain heavily loaded against the endogenous development of small island states and the basic connectivity with elsewhere which makes this development possible.

\section{Discussion}

It seems that the ascendency of resilience, climate change and other environmental discourses flies in the face of the "relational turn" that is prevalent in both natural and social sciences today and from which island studies itself is not exempt. Early debates concerning islandness have proposed and struggled with what appear today as rather facile and neat dichotomies - roots and routes; exotopias and endotopias; open and closed; stranded and mobile; peripheral and central; isolated and connected (DeLoughrey, 2007; Cameron, 2012; Hay, 2006; Sheller, 2013). However, even more powerfully significant towards the critical understanding of island life may be the relationalities and contingencies implicit in looking at flows, fluidities, relations and movements (Stratford et al., 2011). In privileging territoriality, which is a fundamental premise driving both climate change policy, as much as the resilience that it is meant to feed on as well as nurture, one falls victim to the sovereignty trap and neglects the relational turn, doing so - literally - at one's peril (Pugh, 2016a). This is the exasperating situation of small island states, their policymakers and their citizens: their statehood implies sovereignty, but their smallness and islandness suggest survival strategies that must perforce usurp the reductionist strictures of their sovereign space and its (all too visibly finite) material resources (Baldacchino, 2012).

Pugh (2016b), quoting Scott (2014, p. 6), reminds us that "development" and its practice have bred their own disillusionment to the extent that after experiencing decades of independent government, the hopes, dreams and expectations of a post-colonial development may have all but evaporated in many countries, including SIDS. Where SIDS are concerned, an "infinite pause" in decolonisation seems to have stubbornly taken hold (Connell, 2003), with many small states oscillating between economic booms and troughs, a stance which hardly amounts to a sense of development as a trajectory, "going forward" (Baldacchino, 2015, p. 8). Climate change and its associated programmes push the limits of 
IJCCSM

10,2

224

the possibility of development even further away, with actions geared towards bare survivability and security and neglecting individuality (read creolisation in the Caribbean) and creativity along the way. There is neither space nor scope for "thinking big" here: SIDS are stuck together ontologically in defensive mode and where a basic and modest liveability is the new ultimate measure of success. Indeed, this frame of mind is not too different from that form of economic vulnerability assessment which was marked by the onset - and overpowering narrative - of droughts, floods, epidemics, volcanic eruptions, hurricanes and a plethora of other nasty and debilitating events (Briguglio, 1995; Srinivasan, 1986; Turvey, 2007).

\section{Conclusion}

This paper has sought to frame and propose a conceptual position that empowers the reader to adopt a critical focus on the concepts of resilience and sovereignty. In doing so, it questions the usefulness of approaches that tend to channel funding and policy measures to, say, "capacity building" programmes when the capacity to strike out beyond one's sovereign borders, in patterns of permanent or circular migration, is manifestly inhibited. The irony is palpable.

Such arguments may not be new. However, they join a growing body of literature that provides researchers and policymakers with some useful ground to stand on when confronted by the glaringly poorly conceived interpretations of small island life coming not just from international agencies and their mantra of development but also SIDS policymakers themselves. These arguments remind us of how, say, the call by the Pacific island states within the AOSIS to limit global warming, captured in the chant "one point five to stay alive" (SPREP, 2016), is also implicitly about "staying": staying put; staying at home.

The significance of debates about the nature of island life extends well beyond islands and island studies: it may have much to tell and teach us about how we may approach wider questions of relationality, interdependence, connection and various other central tropes and angsts of our time. The re-energised political pursuit of patriotism, nationalism and protectionism of the historical present may need to be confronted, even tamed, with the inherent coming and going - "tidalectics", as Barbadian poet Kamau Brathwaite (2007) calls them - of human lives, poignantly visible in and on those island spaces that geography might appear to have intended most of all to be "insular", in the sense of being isolated and protective of their own.

Meanwhile, how are the mighty and lofty goals of independence fallen: no wonder then that the town planners in their office in Castries, St Lucia, and presumably many like them in other SIDS and beyond, do not much enjoy seeing their "small island state" being reduced as object of chaotic environmental, social and even political flows as well as relational forces that are beyond anyone's control, making short shrift of their state's "independence". They may pine instead for a more exciting and empowering discourse, one that is about seizing history, and considers change well beyond climate change.

\section{References}

Adam, B. and Groves, C. (2007), Future Matters: Action, Knowledge, Ethics, Brill, Leiden.

Agnew, J. (1994), "The territorial trap: the geographical assumptions of international relations theory", Review of International Political Economy, Vol. 1 No. 1, pp. 53-80.

Ayers, J.M. and Huq, S. (2009), "Supporting adaptation to climate change: what role for official development assistance?”, Development Policy Review, Vol. 27 No. 6, pp. 675-692. 
Baldacchino, G. (2006a), "Managing the hinterland beyond: two ideal-type strategies of economic development for small island territories", Asia Pacific Viewpoint, Vol. 47 No. 1, pp. 45-60.

Baldacchino, G. (2006b), "The brain rotation and brain diffusion strategies of small islanders: considering 'movement' in lieu of 'place", Globalisation, Societies and Education, Vol. 4 No. 1, pp. 143-154.

Baldacchino, G. (2012), "Governmentality is all the rage: the strategy games of small jurisdictions”, The Round Table: Commonwealth Journal of International Affairs, Vol. 101 No. 3, pp. 235-251.

Baldacchino, G. (2015), Entrepreneurship in Small Island States and Territories, Routledge, London.

Baldacchino, G. and Bertram, G. (2009), "The beak of the finch: insights into the economic development of small economies", The Round Table: Commonwealth Journal of International Affairs, Vol. 98 No. 401, pp. 141-160.

Baldacchino, G. and Kelman, I. (2014), "Critiquing the pursuit of island sustainability", Shima: The International Journal of Research into Island Cultures, Vol. 8 No. 2, pp. 1-21.

Baldacchino, G. and Royle, S.A. (2010), "Postcolonialism and islands: introduction”, Space and Culture, Vol. 13 No. 2, pp. 140-143.

Barnett, J. and Campbell, J. (2010), Climate Change and Small Island States: Power, Knowledge, and the South Pacific, Earthscan, New York, NY.

Berlant, L.G. (2011), Cruel Optimism, Duke University Press, Durham NC.

Bongie, C. (1998), Islands and Exiles: The Creole Identities of Post/Colonial Literature, Stanford University Press, Stanford CA.

Brathwaite, K. (2007), Caribbean Culture: Soundings on Kamau Brathwaite, University of West Indies Press, Mona, Jamaica.

Briguglio, L. (1995), "Small island developing states and their economic vulnerabilities", World Development, Vol. 23 No. 9, pp. 1615-1632.

Briguglio, L. (1998), "Small country size and returns to scale in manufacturing", World Development, Vol. 26 No. 3, pp. 507-515.

Briguglio, L., Cordina, G., Farrugia, N. and Vella, S. (2009), "Economic vulnerability and resilience: concepts and measurements", Oxford Development Studies, Vol. 37 No. 3, pp. 229-247.

Brondizio, E.S. and Syvitski, J. (2016), "Editorial: the anthropocene", Global Environmental Change, Vol. 39 No. 1, pp. 316-317.

Burton, I., Huq, S., Lim, B., Pilifosova, O. and Schipper, E.L. (2002), "From impacts assessment to adaptation priorities: the shaping of adaptation policy", Climate Policy, Vol. 2 Nos 2/3, pp. 145-159.

Cameron, A. (2012), "Splendid isolation: 'philosopher's islands' and the reimagination of space", Geoforum, Vol. 43 No. 4, pp. 741-749.

Caramel, L. (2014), "Besieged by the rising tides of climate change, Kiribati buys land in Fiji", The Guardian, available at: www.theguardian.com/environment/2014/jul/01/kiribati-climate-changefiji-vanua-levu

CCU (2016), "The climate change and disaster risk management unit", Organisation of Eastern Caribbean States (OECS), available at: www.oecs.org/ccu-about

Chaudhuri, U. and Enelow, S. (2014), "Theorizing ecocide: the theatre of eco-cruelty", in Research Theatre, Climate Change, and the Ecocide Project: A Casebook, Palgrave Macmillan, New York, NY, pp. 22-40.

Collado, R. (2016), "Vanishing island nations: the case for the Maldives", available at: www. geopoliticalmonitor.com/vanishing-island-nations-the-case-for-the-maldives/

Connell, J. (2003), "New Caledonia: an infinite pause in decolonization?", The Round Table: Commonwealth Journal of International Affairs, Vol. 92 No. 368, pp. 125-143.
Development and nonclimate change 
IJCCSM 10,2

Connell, J. (2013), Islands at Risk? Environments, Economies and Contemporary Change, Edward Elgar Publishing, Cheltenham.

Constant, A.F., Nottmeyer, O. and Zimmermann, K.F. (2013), "The economics of circular migration”, in Constant, A.F. and Zimmermann, K.F. (Eds), International Handbook on the Economics of Migration, Edward Elgar Publishing, Cheltenham, pp. 55-74.

Cooper, A.F. (2011), Internet Gambling Offshore: Caribbean Struggles over Casino Capitalism, Palgrave Macmillan, New York, NY.

Cooper, A.F. and Shaw, T. (Eds) (2009), The Diplomacies of Small States: Between Vulnerability and Resilience, Palgrave Macmillan, New York, NY.

De Souza, R.M., Henly-Shepard, S., McNamara, K. and Fernando, N. (2015), "Re-framing island nations as champions of resilience in the face of climate change and disaster risk", United Nations University, Working Paper No. 9, available at: https:/i.unu.edu/media/ehs.unu.edu/news/3890/ resilience_academy_wp9.pdf

DeLoughrey, E.M. (2007), Routes and Roots: Navigating Caribbean and Pacific Island Literatures, University of Hawaii Press, Honolulu HI.

Ellis, G. (2005), "St Lucia’s declining banana trade”, BBC News, 2 August, available at: http://news.bbc. co.uk/1/hi/world/americas/4737473.stm

Embassy of the Maldives in London (2014), "President Yameen inaugurates Maldives investment forum in Singapore", available at: www.maldiveshighcommission.org/news/news-from-maldives/item/500president-yameen-inaugurates-maldives-investment-forum-in-singapore

Evans, B. and Reid, J. (2014), Resilient Life: The Art of Living Dangerously, John Wiley \& Sons, New York, NY.

Farbotko, C. (2010a), "The global warming clock is ticking so see these places while you can': voyeuristic tourism and model environmental citizens on Tuvalu's disappearing islands", Singapore Journal of Tropical Geography, Vol. 31 No. 2, pp. 224-238.

Farbotko, C. (2010b), "Wishful sinking: disappearing islands, climate refugees and cosmopolitan experimentation", Asia Pacific Viewpoint, Vol. 51 No. 1, pp. 47-60.

Fichera, M. and Hänninen, S. (2016), Polity and Crisis: Reflections on the European Odyssey, Routledge, London.

Gay, J.C. (2014), "Global warming and the exploitation of small island states”, L’Espace Géographique, Vol. 43 No. 1, pp. 81-89.

Gosden, C. and Pavlides, C. (1994), "Are islands insular? Landscape vs. seascape in the case of the Arawe Islands, Papua New Guinea”, Archaeology in Oceania, Vol. 29 No. 3, pp. 162-171.

Grove, K. (2014), "Agency, affect, and the immunological politics of disaster resilience”, Environment and Planning D: Society and Space, Vol. 32 No. 2, pp. 240-256.

Grydehøj, A. (2016), "Navigating the binaries of island independence and dependence in Greenland: decolonization, political culture, and strategic services”, Political Geography, Vol. 55 No. 1, pp. 102-112.

Grydehøj, A. and Kelman, I. (2016), "The eco-island trap: climate change mitigation and conspicuous sustainability", Area, Vol. 49 No. 1, pp. 106-113., doi: 10.1111/area.12300.

Guibernau, M. (2013), Nationalisms: The Nation-State and Nationalism in the Twentieth Century, John Wiley \& Sons, New York, NY.

Hau'ofa, E. (1994), “Our sea of islands”, The Contemporary Pacific, Vol. 6 No. 1, pp. 148-161.

Hay, P. (2006), “A phenomenology of islands”, Island Studies Journal, Vol. 1 No. 1, pp. 19-42.

Henderson, J. and Denny, K. (2015), "The resilient child, human development and the 'postdemocracy", BioSocieties, Vol. 10 No. 3, pp. 352-378.

Huff-Rousselle, M. and Burnett, F. (1996), "Cost containment through pharmaceutical procurement: a Caribbean case study", The International Journal of Health Planning and Management, Vol. 11 No. 1, pp. 135-157. 
Kelman, I. (2010), "Dealing with climate change on small island developing states", Practising Anthropology, Vol. 33 No. 1, pp. 28-32.

Kelman, I. (2016), "Governance of climate change adaptation on Small Island Developing States (SIDS)", in Knieling, J. (Ed.), Climate Adaptation Governance in Cities and Regions: Theoretical Fundamentals and Practical Evidence, Wiley-Blackwell, New York, NY, pp. 355-370.

King, R. (2009), "Geography, islands and migration in an era of global mobility”, Island Studies Journal, Vol. 4 No. 1, pp. 85-98.

King, R. and Connell, J. (Eds) (1999), Small Worlds, Global Lives: Small Islands and Migration, Pinter, London.

Launder, B. and Thompson, J.M.T. (2009), Geo-Engineering Climate Change, Cambridge University Press, New York, NY.

Mawby, S. (2012), Ordering Independence: The End of Empire in the Anglophone Caribbean, 1947-69, Palgrave Macmillan, New York, NY.

Morozov, E. (2014), To Save Everything, Click Here: The Folly of Technological Solutionism, PublicAffairs, New York, NY.

Munro, D. (1990), "Transnational corporations of kin and the MIRAB system: the case of Tuvalu", Pacific Viewpoint, Vol. 31 No. 1, pp. 63-66.

Neumann, I.B. and Gstöhl, S. (2004), "Lilliputians in Gulliver's world” in Ingebritsen, C., Neumann, I.B. and Gstöhl, S. (Eds), Small States in International Relations, University of Washington Press and University of Iceland Press: Seattle WA and Reykjavik, Iceland, pp. 3-38.

Palan, R. (2006), The Offshore World: Sovereign Markets, Virtual Places and Nomad Millionaires, Cornell University Press, Ithaca, NY.

Pelling, M. and Uitto, J.I. (2001), "Small island developing states: natural disaster vulnerability and global change", Global Environmental Change Part B: Environmental Hazards, Vol. 3 No. 2, pp. 49-62.

Philpot, D., Gray, T.S. and Stead, S.M. (2015), "Seychelles, a vulnerable or resilient SIDS? A local perspective", Island Studies Journal, Vol. 10 No. 1, pp. 31-48.

Prasad, N. (2004), "Escaping regulation, escaping convention: development strategies in small economies", World Economics, Vol. 5 No. 1, pp. 41-65.

Pugh, J. (2016a), "The relational turn in island geographies: bringing together island, sea and ship relations and the case of the Landship", Social \& Cultural Geography, Vol. 17 No. 8, pp. 1040-1059.

Pugh, J. (2016b), "Postcolonial development, (non) sovereignty and affect: living on in the wake of Caribbean political independence", Antipode, Vol. 49 No. 4, pp. 867-882., doi: 10.1111/ anti.12305.

Rabidas, U. (2016), "Services measures of the United States and the OECD and the search for "Caribbean resilience': keeping dependence in perspective”, Asian Journal of Latin American Studies, Vol. 29 No. 3, pp. 55-74.

Roberts, S., Telesford, J.N. and Barrow, J.V. (2015), "Navigating the Caribbean archipelago: an examination of regional transportation issues", in G. Baldacchino (Ed.), Archipelago Tourism: Policies and Practices, Ashgate, Farnham, pp. 147-162.

Sabel, C.F. and Zeitlin, J. (2010), Experimentalist Governance in the European Union: Towards a New Architecture, Oxford University Press, Oxford.

Santos-Paulino, A., McGillivray, M. and Naudé, W. (2010), Understanding Small Island Developing States: Fragility and External Shocks, Routledge, London.

Schaffer, B. (1975), "The politics of dependence", in Selwyn, P. (Ed.), Development Policy in Small Countries, Croom Helm, London, pp. 24-53.

Scott, D. (2014), Omens of Adversity: Tragedy, Time, Memory, Justice, Duke University Press, Durham NC.
Development and nonclimate change 
IJCCSM

10,2

Sheller, M. (2013), “The islanding effect: post-disaster mobility systems and humanitarian logistics in Haiti”, Cultural Geographies, Vol. 20 No. 2, pp. 185-204.

SPREP (2016), "1.5 to Stay Alive" to be Supported by IPCC Report, Apia, Samoa: Secretariat of the Pacific Regional Environment Programme, available at: www.sprep.org/climate-change/q15-tostay-aliveq-to-be-supported-by-ipcc-report

Srinivasan, T.N. (1986), "The costs and benefits of being a small, remote, island, landlocked, or ministate economy", The World Bank Research Observer, Vol. 1 No. 2, pp. 205-218.

Stewart, K. (2011), “Atmospheric attunements", Environment and Planning D: Society and Space, Vol. 29 No. 3, pp. 445-453.

Stratford, E., Baldacchino, G., McMahon, E., Farbotko, C. and Harwood, A. (2011), "Envisioning the archipelago", Island Studies Journal, Vol. 6 No. 2, pp. 113-130.

The Economist (2016), "The last liberals: why Canada is still at ease with openness", available at: www. economist.com/news/briefing/21709291-why-canada-still-ease-openness-last-liberals

Turner, B. (2015), "Organisation of Eastern Caribbean States (OECS)”, in Heath-Brown, N. (Ed.) The Statesman's Yearbook: The Politics, Cultures and Economies of the World 2015, Palgrave Macmillan UK, London, pp. 66-66.

Turvey, R. (2007), "Vulnerability assessment of developing countries: the case of small-island developing states", Development Policy Review, Vol. 25 No. 2, pp. 243-264.

Urbina, D. (2016), "Perils of climate change could swamp coastal real estate", New York Times, available at: www.nytimes.com/2016/11/24/science/global-warming-coastal-real-estate.html?_r=0

Urry, J. (2016), What Is the Future?, John Wiley \& Sons, New York, NY.

Vlcek, W. (2008), Offshore Finance and Small States: Sovereignty, Size and Money, Springer, New York, NY.

Vlcek, W. (2016), Offshore Finance and Global Governance: Disciplining the Tax Nomad, Springer, New York, NY.

Ward, R.G. (1989), "Earth's empty quarter? The pacific islands in a pacific century", Geographical Journal, Vol. 155 No. 2, pp. 235-246.

Webb, A.P. and Kench, P.S. (2010), "The dynamic response of reef islands to sea-level rise: evidence from multi-decadal analysis of island change in the central pacific", Global and Planetary Change, Vol. 72 No. 3, pp. 234-246.

Wyett, K. (2014), "Escaping a rising tide: sea level rise and migration in Kiribati", Asia \& the Pacific Policy Studies, Vol. 1 No. 1, pp. 171-185.

\section{Corresponding author}

Godfrey Baldacchino can be contacted at: godfrey.baldacchino@um.edu.mt

For instructions on how to order reprints of this article, please visit our website: 